\title{
SALT AND CRUDE PLANT EXTRACTS AS PRESERVATIVES IN A MEAT MODEL SYSTEM (GROUND PORK SHOULDER) ${ }^{1}$
}

\author{
ALINE ANIELE VENCATO ${ }^{2}$, VINICIUS SASSO NICKEL ${ }^{3}$, MAGNÓLIA APARECIDA SILVA DA SILVA ${ }^{4}$, LIRIS \\ KINDLEIN $^{5}$, GUIOMAR PEDRO BERGMANN ${ }^{5}$, CÉSAR AUGUSTO MARCHIONATTI AVANCINI ${ }^{5 *}$
}

\begin{abstract}
Health risks associated with conventional preservatives and the trend of food healthiness have promoted a growing interest in alternatives of food preservation. These include the use of plant preservatives, condiments and their extracts. Using the indicators count of aerobic mesophiles and $\mathrm{pH}$, the objective of this study was to compare the influence of salt content at the proportions of one, two and three parts with that of the addition of crude plant extracts on the time of preservation of a meat model system $(600 \mathrm{~g}$ of ground pork shoulder). It was considered suitable for human consumption the treatment whose microbiological count of aerobic mesophiles, observed for 15 days, did not exceed $10^{5} \mathrm{CFU} / \mathrm{g}$. The components (salt and extracts) were mixed with the meat using a Stomacher Lab Blender. The treatment with the highest proportion of salt (three parts) remained viable for consumption for 10 days, while treatments with one part remained for four days and those with two parts remained for nine days. Treatments with "macela" or "laurel" did not statistically differ from treatments with one part of salt. The extracts of "hibiscus", "clove", "cinnamon" and "nutmeg", in the plant:volume proportion $(10 \mathrm{~g}: 100 \mathrm{~mL})$ tested, maintained the meat model system suitable for consumption until the fifteenth day. The $\mathrm{pH}$ of the treatments did not interfere with the shelf life of the meat model system. The results indicate the potential use of these extracts as preservatives in processed meat products.
\end{abstract}

Keywords: Preservative condiments. Preservative spices. Food preservatives. Plant preservatives.

\section{SAL E EXTRATOS VEGETAIS BRUTOS COMO CONSERVANTES EM MODELO CÁRNEO (PALETA SUÍNA MOÍDA)}

\begin{abstract}
RESUMO - Os riscos à saúde atribuídos aos conservantes convencionais e a tendência de saudabilidade dos alimentos promoveram um crescente interesse por alternativas para a preservação dos alimentos. Entre elas a utilização de conservantes de origem vegetal, os condimentos e os extratos deles obtidos. Usando como indicadores a contagem de mesófilos aeróbios e o $\mathrm{pH}$, este trabalho teve como objetivo comparar a influência do teor de sal nas proporções uma, duas e três partes com o da adição de extratos vegetais brutos no tempo de conservação de modelo cárneo (600 g de carne de paleta suína moída). Considerou-se apto para consumo o tratamento cuja contagem de mesófilos, observados por 15 dias, não ultrapassasse $10^{5} \mathrm{UFC} / \mathrm{g}$. Os componentes (sal e extratos) foram misturados ao modelo cárneo usando aparelho Stomacher. O tratamento com a maior proporção de sal (três partes) permaneceu 10 dias viável para o consumo, enquanto os tratamentos com uma parte por quatro dias e duas partes por 9 dias. Os tratamentos com extratos de "macela" e de "louro" não diferiram estatisticamente do tratamento com uma parte de sal. Os extratos de "hibisco", de "cravo", de "canela" e de "noz-moscada", na proporção planta : volume (10 g :100 mL) testados, mantiveram o modelo cárneo apto para o consumo até o décimo quinto dia. $\mathrm{O} \mathrm{pH}$ dos tratamentos não interferiu no tempo de preservação do modelo cárneo. As evidências indicam o potencial uso desses extratos como conservantes em produtos cárneos processados.
\end{abstract}

Palavras-chave: Condimentos conservantes. Especiarias conservantes. Preservantes de alimentos. Preservantes vegetais.

\footnotetext{
*Corresponding author

${ }^{1}$ Received for publication in $08 / 21 / 2019$; accepted in $03 / 12 / 2020$.

Paper extracted from the master's monograph of the first auhor.

${ }^{2}$ Professional Master's in Food of Animal Origin, Universidade Federal do Rio Grande do Sul, Porto Alegre, RS, Brazil; aline_vencato@hotmail.com-ORCID: 0000-0002-5884-7859.

${ }^{3}$ Meat Research, Teaching and Tecnology Center, Universidade Federal do Rio Grande do Sul, Porto Alegre, RS, Brazil; vininickel@hotmail.com - ORCID: 0000-0002-2125-4363.

${ }^{4}$ Horticulture and Silviculture Departament, Faculty of Agronomy, Universidade Federal do Rio Grande do Sul, Porto Alegre, RS, Brazil; magnolia.silva@ufrgs.br-ORCID: 0000-0003-4492-8938.

${ }^{5}$ Post-Graduation Program in Food of Animal Origin, Universidade Federal do Rio Grande do Sul, Porto Alegre, RS, Brazil; liris.kindlein@ufrgs.br - ORCID: 0000-0002-3925-1128, guiomar.bergmann@ufrgs.br - ORCID: 0000-0003-0440-948X, cesar.avancini@ufrgs.br-ORCID: 0000-0002-2404-2796.
} 


\section{INTRODUCTION}

Deterioration involves any change that makes food unsuitable for human consumption. In fresh foods, such as meat, the main changes in quality occur due to bacterial multiplication, which result in the formation of gas with unpleasant odors, formation of slimy layers, oxidation of lipids and pigments, leading to undesirable flavor and presence of compounds with toxic biological effects (FORSYTHE, 2013).

In order to increase the time between production and the point at which food is still suitable for human consumption (shelf life), there are different methods of preservation, whose primary function is to delay deterioration, such as heating, cooling, freezing, drying, acidification, fermentation and preservative additives (VASCONSELOS; MELO FILHO, 2010).

Preservatives used as a preservation method are classified as artificial and natural (SHARIF et al., 2017). For some years now, the scientific literature has demonstrated the existence of risks inherent to the use of artificial preservatives (nitrates, benzoates, sulfites and sorbates, among others) in food (SULTANA et al., 2014; BISSACOTTI; ANGST; SACCOL, 2015; INETIANBOR; YAKUBU; EZEONU, 2016) and that many of them are involved in the causing of acute or chronic diseases such as allergic reactions (ZAKNUN et al., 2012) and carcinogenic effects (KIM; CHO; HAN, 2013; JAVANMARDI et al., 2019). Even conventional preservatives that have natural origin (e.g., sugar and salt) are having their use questioned because they cause, or aggravate, health problems such as diabetes and hypertension (NILSON; JAIME; RESENDE, 2012; SCAPIN; FERNANDES; PROENÇA, 2017).

The above-mentioned health risks have promoted a growing interest in research for alternatives to conventional food preservation products (SINGH; SHARMA; GARG, 2010). Among the alternatives is the use of preservatives obtained from foods of natural plant origin, condiments and the extracts obtained from them (JAY, 2005; BANON et al., 2007). Plants produce a diversity of secondary metabolites to protect themselves from predators and phytopathogens, and many of them can be used as antimicrobial preservatives (GYAWALI; IBRAHIM, 2014; PISOSCHI et al., 2018), serving as a source to ensure food safety and increase the shelf life of food products (HYGREEVA; PANDEY; RADHAKRISHNA, 2014; HAFSA et al., 2016).

The general objective of this study was to compare the preservative activity of refined sea salt with that of plant extracts, aiming at the potential use of extracts in the processing of fresh meat products. The specific objective was to verify the influence of salt content at the proportions of one, two and three parts compared to the addition of crude plant extracts on the time of preservation of meat model (ground pork shoulder), using the indicators microbiological count of aerobic mesophiles and $\mathrm{pH}$.

\section{MATERIAL AND METHODS}

\section{Plant extracts}

Through the review of scientific literature on antimicrobial activity of plant extracts, the following plants were selected for the experiment: Achyrocline satureioides ("macela"), whose inflorescences were used; Hibiscus sabdariffa L. ("hibiscus"), whose sepals and dehiscent capsules were used; Caryophyllus aromaticus L. ("clove"), whose dry flower buds were used; Cinnamomum zeylanicum ("cinnamon"), whose bark was used; Laurus nobilis ("laurel"), whose leaves were used, and Myristica fragrans ("nutmeg"), whose seeds/nuts were used. The products were obtained at the market and placed in plastic packaging, all of them registered with the National Health Surveillance Agency (ANVISA). The label contained the name of the technician responsible for the taxonomic identification.

Crude plant extracts were prepared through maceration in hydroalcoholic solution. The plant parts were fragmented, placed in glass containers and immersed in the ethanol solvent at $70^{\circ} \mathrm{GL}$ (SIMÕES et al., 2003; SANTOS et al., 2014). The closed containers were kept at room temperature for 30 days and were manually stirred once a day.

The proportions between mass of plant by volume of alcohol (weight: volume) were $10 \mathrm{~g}: 100$ $\mathrm{mL} \quad(=100 \mathrm{mg} / \mathrm{mL})$ for "hibiscus", "clove", "cinnamon" and "nutmeg", $7.5 \mathrm{~g}$ : $100 \mathrm{~mL}$ (=75 mg/ $\mathrm{mL}$ ) for "laurel", and $5 \mathrm{~g}: 100 \mathrm{~mL}(=50 \mathrm{mg} / \mathrm{mL})$ for "macela". The proportions used in the maceration were not all the same because, in the case of "laurel" and "macela", the volume of the plant did not allow the plant mass to be completely immersed in the solvent.

After the maceration time, filtering was performed using sterile paper bottles and bags. To obtain the crude extracts, the solutions were subjected to alcohol evaporation under reduced pressure, using a rotary evaporator at $60{ }^{\circ} \mathrm{C}$. After evaporation, the initial volume of the solutions was reconstituted by adding sterile distilled water.

The sterility control of the plant extracts was performed on the day of the mixing with ground meat.

The sea salt used was also commercial and its ingredients were refined salt (390 mg sodium/1 g), potassium (25 mg/1g), anti-humectant, sodium ferrocyanide and silicon dioxide. As with the plant materials, the product was registered with ANVISA. 
Meat model and total aerobic mesophilic bacterial count and pH

The meat model in this experiment was composed of $600 \mathrm{~g}$ of ground meat plus the specific proportions of components for each treatment.

The meat used was deboned pork shoulder, purchased at slaughterhouse with inspection origin identified by the seal of the Federal Inspection Service (Serviço de Inspeção Federal - SIF). The meat was ground in a meat grinder, with granulometry of $\pm 8 \mathrm{~mm}$, separated into packages (bags for Stomacher ${ }^{\circledR}$ sample mixer) by mass, according to the meat model for each treatment of the experiment, and kept frozen.

The tests for monitoring the parameters were based on the methodologies of Normative Instruction/MAPA No. 20 of July 21, 1999, which officializes the Physical-Chemical Analytical
Methods for the Control of Meat Products and their Ingredients - Salt and Brine (BRASIL, 1999) and Normative Instruction/MAPA No. 62, of August 26, 2003, which officializes the Analytical Methods for Microbiological Analysis for Control of Animal Products and Water (BRASIL, 2003).

The Brazilian legislation (BRASIL, 2001) does not establish limits of tolerance for the group of aerobic mesophilic microorganisms. Therefore, it was decided to consider as a meat model suitable for human consumption the experimental unit that showed a maximum exponential of $10^{5} \mathrm{CFU} / \mathrm{g}$.

\section{Experimental design and statistical analysis}

The experiment consisted in monitoring the meat model in its different treatments, (Table 1) evaluating the microbiological parameters aerobic mesophiles and $\mathrm{pH}$ from the 1 st to the $15^{\text {th }}$ day.

Table 1. Experimental design to monitor the meat model in its different treatments, evaluating the microbiological parameters aerobic mesophiles and $\mathrm{pH}$.

\begin{tabular}{|c|c|}
\hline Treatment 0 (T0) & $\begin{array}{l}\text { Fresh meat model ( } 600 \mathrm{~g} \text { of ground meat), without salt and without freezing, on the } \\
\text { meat purchase day. }\end{array}$ \\
\hline Treatment 1 (T1) & Meat model (600 g of ground meat) without salt, frozen. \\
\hline Treatment $2(\mathrm{~T} 2)$ & $\begin{array}{l}\text { Meat model ( } 600 \mathrm{~g} \text { of ground meat) }+ \text { one part of salt }(6 \mathrm{~g} \text { of salt diluted in } 60 \mathrm{~mL} \\
\text { of water - control for statistical analysis). }\end{array}$ \\
\hline Treatment 3 (T3) & $\begin{array}{l}\text { Meat model }(600 \mathrm{~g} \text { of ground meat })+\text { two parts of salt }(12 \mathrm{~g} \text { of salt diluted in } 60 \\
\mathrm{mL} \text { of water). }\end{array}$ \\
\hline Treatment 4 (T4) & $\begin{array}{l}\text { Meat model }(600 \mathrm{~g} \text { of ground meat })+\text { three parts of salt }(18 \mathrm{~g} \text { of salt diluted in } 60 \\
\mathrm{mL} \text { of water). }\end{array}$ \\
\hline Treatment 5 (T5) & Meat model $(600 \mathrm{~g}$ of ground meat $)+$ one part of salt $+60 \mathrm{~mL}$ of "macela" extract. \\
\hline Treatment 6 (T6) & $\begin{array}{l}\text { Meat model }(600 \mathrm{~g} \text { of ground meat })+\text { one part of salt }+60 \mathrm{~mL} \text { of "hibiscus" } \\
\text { extract. }\end{array}$ \\
\hline Treatment 7 (T7) & Meat model (600 g of ground meat) + one part of salt $+60 \mathrm{~mL}$ of "laurel" extract. \\
\hline Treatment 8 (T8) & $\begin{array}{l}\text { Meat model ( } 600 \mathrm{~g} \text { of ground meat })+ \text { one part of salt }+60 \mathrm{~mL} \text { of "cinnamon" } \\
\text { extract. }\end{array}$ \\
\hline Treatment 9 (T9) & Meat model (600 g of ground meat) + one part of salt $+60 \mathrm{~mL}$ of "clove" extract. \\
\hline Treatment 1 & Meat model (600 g of ground meat) + one part of salt $+60 \mathrm{~mL}$ of "nutmeg" extract. \\
\hline
\end{tabular}

In Treatment zero (T0), the meat was analyzed on the day of purchase, still fresh, in order to measure the mesophilic parameter (population density). For the rest of the experiment, due to the logistics of execution of the other nine Treatments, the ground meat was frozen as reported above. Thawing began on the day prior to the tests: the packed frozen ground meat was placed in a refrigerator for approximately 30 hours for complete thawing.

For each Treatment, the thawed meat model was placed for stirring in a Stomacher apparatus, mixed with $60 \mathrm{~mL}$ of water and with water with the specific amounts of salt (one, two or three parts) and/ or extract, until complete homogenization. Afterwards, it was divided into $40 \mathrm{-g}$ portions and placed in 16 sterile Petri dishes, one for each observation day. On each observation day, $25 \mathrm{~g}$ were collected, in duplicate, to count the aerobic mesophilic microorganisms and $10 \mathrm{~g}$ were collected, also in duplicate, to check $\mathrm{pH}$. During the experiments, Petri dishes remained under refrigeration at $\pm 7{ }^{\circ} \mathrm{C}$.

In the construction of the statistical analysis 
database, the logarithm of the data over the days was used for aerobic mesophiles, and the data over the days were used for $\mathrm{pH}$. In order to reduce the error, two measurements were performed in the same sample, using the means of the two for each Treatment and day.

For comparison between Treatments and between days, due to the non-normality of the data for both $\log$ mesophilic count and $\mathrm{pH}$, KruskalWallis nonparametric statistical tests were used to compare medians, instead of parametric tests of ANOVA for comparison of means.

The statistical analyses were performed using the R Software, with the graphics packages ggplot2 and mvnormtest.

\section{RESULTS AND DISCUSSION}

The evaluation of salt included in this investigation because, in addition to comparing its activity as a preservative with the activity of crude plant extracts, the general objective of the study is to use it in the processing of fresh meat products. With this purpose, the function of salt in processed meat products is to solubilize meat myofibrillar proteins, and most meat products depend on this property to generate texture characteristics (BANNWART; MR. SILVA; VIDAL, 2014).

In addition, as an example of a fresh meat product, for the processing of sausage the Technical Regulation of Identity and Quality (Regulamento Técnico de Identidade e Qualidade - RTIQ) (BRASIL, 2000) specifies the obligation to contain salt in its formulation. As the general objectives of this study included the simulation to make products with healthiness characteristics, this was the reason why T2 (lower proportion of salt) was used as a control for statistical evaluation.

The results and statistical analysis for the aerobic mesophilic count and $\mathrm{pH}$ will be presented separately.

\section{Description and interpretation of the results for aerobic mesophilic bacterial count}

As reported in the previous section, there is no delimitation in Brazilian legislation for the quantification of aerobic mesophiles. However, Forsythe (2013) observed that the shelf life of meats becomes compromised when populations of aerobic mesophilic bacteria exceed $10^{6} \mathrm{CFU} / \mathrm{g}$. According to this author, with count of $1 \times 10^{7} \mathrm{CFU} / \mathrm{g}$ the ground meat already exhibits discoloration and biofilm formation. Likewise, the observations of Jay (2005) are in line with this, as the author states that degradation begins from $10^{6} \mathrm{CFU} / \mathrm{g}$, and in ground meat the first signs of deterioration are the development of unpleasant odors followed by a sticky consistency, which motivated the choice of this limit for the mesophilic population density to consider ground meat suitable for consumption.

Table 2 shows the count of aerobic mesophilic bacteria (CFU/g) in a meat model (pork shoulder) in different Treatments along the 15 days of experiment.

Descriptive comparison between $\mathrm{T} 0$ and $\mathrm{T} 1$ : it was observed that $\mathrm{T} 0$ and $\mathrm{T} 1$ had similar counts of aerobic mesophilic bacteria, remaining suitable for consumption from the microbiological point of view until the seventh day for T0 and until the sixth day for $\mathrm{T} 1$, leading to the conclusion that the freezing and thawing process did not interfere in the result for this parameter. All Treatments started with the same exponential logarithm $\left(10^{3} \mathrm{CFU} / \mathrm{g}\right)$.

Descriptive comparison between $\mathrm{T} 1$ and salt Treatments: while T1 was suitable for consumption until the sixth day, T2 remained suitable until the fourth day, T3 remained until the ninth day and T4 remained viable until the tenth day of refrigerated storage. Therefore, it was observed that adding 2 and 3 parts of salt increased the shelf life of the meat model compared to that without salt. However, when one part of salt was added to the meat model, there was a reduction in shelf life compared to $\mathrm{T} 1$, as it remained suitable for consumption only until the fourth day of storage, which may have been caused by contamination during handling.

Descriptive comparison between salt Treatments: as can be read in the paragraph above, among the Treatments with salt, T4, with the highest proportion of salt, was the one that promoted the longest shelf life conservation time of the meat model under refrigerated storage, indicating that in addition to the technological function in the processing of pork, it also seemed to be a variable that interferes in the increase of shelf life.

However, as can be seen hereinafter, no significant statistical difference between Treatments with different salt proportions was confirmed. 
A. A. VENCATO et al

Table 2. Aerobic mesophilic bacteria count (CFU/g) in meat model (ground pork shoulder) in different Treatments over 15 days.

\begin{tabular}{|c|c|c|c|c|c|c|c|c|c|c|}
\hline T0 & T1 & T2 & T3 & T4 & T5 & T6 & T7 & T8 & T9 & T10 \\
\hline $3.8 \times 10^{3}$ & $7.6 \times 10^{3}$ & $3.9 \times 10^{3}$ & $3.4 \times 10^{3}$ & $3.7 \times 10^{3}$ & $6.5 \times 10^{3}$ & $5.3 \times 10^{3}$ & $7.1 \times 10^{3}$ & $6.3 \times 10^{3}$ & $6.9 \times 10^{3}$ & $3.5 \times 10^{3}$ \\
\hline $2.8 \times 10^{3}$ & $3.6 \times 10^{3}$ & $7.7 \times 10^{3}$ & $2.9 \times 10^{3}$ & $4.3 \times 10^{3}$ & $3.4 \times 10^{3}$ & $2.1 \times 10^{3}$ & $4.3 \times 10^{3}$ & $1.2 \times 10^{3}$ & $2.0 \times 10^{3}$ & $6.2 \times 10^{3}$ \\
\hline $5.8 \times 10^{3}$ & $5.6 \times 10^{3}$ & $1.0 \times 10^{4}$ & $1.4 \times 10^{4}$ & $3.8 \times 10^{3}$ & $7.9 \times 10^{3}$ & $3.5 \times 10^{3}$ & $5.9 \times 10^{3}$ & $3.7 \times 10^{3}$ & $5.0 \times 10^{3}$ & $4.9 \times 10^{3}$ \\
\hline $1.8 \times 10^{4}$ & $1.4 \times 10^{4}$ & $1.5 \times 10^{4}$ & $4.3 \times 10^{4}$ & $6,8 \times 10^{3}$ & $1.0 \times 10^{4}$ & $2.6 \times 10^{3}$ & $8.0 \times 10^{4}$ & $4.6 \times 10^{3}$ & $4.0 \times 10^{3}$ & $3.6 \times 10^{3}$ \\
\hline $1.7 \times 10^{4}$ & $6.2 \times 10^{4}$ & $2.2 \times 10^{5}$ & $8.5 \times 10^{4}$ & $2.7 \times 10^{4}$ & $1.7 \times 10^{4}$ & $3.5 \times 10^{3}$ & $2.6 \times 10^{5}$ & $2.3 \times 10^{3}$ & $2.7 \times 10^{3}$ & $6.0 \times 10^{3}$ \\
\hline $2.5 \times 10^{4}$ & $6.7 \times 10^{5}$ & $1.3 \times 10^{6}$ & $2.1 \times 10^{4}$ & $2.6 \times 10^{4}$ & $4.1 \times 10^{4}$ & $1.7 \times 10^{3}$ & $2.1 \times 10^{5}$ & $2.5 \times 10^{3}$ & $4.2 \times 10^{3}$ & $2.8 \times 10^{3}$ \\
\hline $7.6 \times 10^{5}$ & $2.7 \times 10^{5}$ & $2.7 \times 10^{6}$ & $1.1 \times 10^{4}$ & $7.8 \times 10^{4}$ & $7.1 \times 10^{5}$ & $5.2 \times 10^{3}$ & $7.2 \times 10^{6}$ & $4.1 \times 10^{3}$ & $1.5 \times 10^{3}$ & $2.0 \times 10^{3}$ \\
\hline $2.9 \times 10^{5}$ & $3.4 \times 10^{6}$ & $1.1 \times 10^{7}$ & $3.3 \times 10^{4}$ & $1.2 \times 10^{5}$ & $1.1 \times 10^{6}$ & $1.5 \times 10^{3}$ & $1.7 \times 10^{6}$ & $8.0 \times 10^{3}$ & $4.0 \times 10^{3}$ & $5.8 \times 10^{3}$ \\
\hline $3.5 \times 10^{6}$ & $2.3 \times 10^{7}$ & $1.5 \times 10^{7}$ & $1.1 \times 10^{5}$ & $2.0 \times 10^{5}$ & $9.2 \times 10^{6}$ & $2.5 \times 10^{3}$ & $3.3 \times 10^{6}$ & $2.1 \times 10^{3}$ & $5.0 \times 10^{4}$ & $2.0 \times 10^{3}$ \\
\hline $5.2 \times 10^{6}$ & $2.9 \times 10^{7}$ & $3.7 \times 10^{7}$ & $3.6 \times 10^{5}$ & $1.4 \times 10^{5}$ & $2.8 \times 10^{6}$ & $2.9 \times 10^{3}$ & $8.1 \times 10^{6}$ & $5.4 \times 10^{3}$ & $1.4 \times 10^{5}$ & $6.4 \times 10^{3}$ \\
\hline $3.3 \times 10^{6}$ & $4.2 \times 10^{7}$ & $7.6 \times 10^{7}$ & $2.2 \times 10^{6}$ & $6.0 \times 10^{5}$ & $2.8 \times 10^{6}$ & $1.0 \times 10^{4}$ & $1.6 \times 10^{6}$ & $3.5 \times 10^{3}$ & $5.4 \times 10^{5}$ & $2.2 \times 10^{3}$ \\
\hline $9.7 \times 10^{6}$ & $3.2 \times 10^{7}$ & $2.0 \times 10^{7}$ & $3.4 \times 10^{6}$ & $2.5 \times 10^{6}$ & $2.9 \times 10^{6}$ & $3.6 \times 10^{4}$ & $4.3 \times 10^{6}$ & $8.1 \times 10^{3}$ & $1.7 \times 10^{5}$ & $1.1 \times 10^{4}$ \\
\hline $3.1 \times 10^{6}$ & $2.5 \times 10^{7}$ & $1.3 \times 10^{7}$ & $5.0 \times 10^{6}$ & $1.8 \times 10^{6}$ & $5.4 \times 10^{6}$ & $8.9 \times 10^{4}$ & $2.7 \times 10^{6}$ & $1.6 \times 10^{4}$ & $1.4 \times 10^{5}$ & $1.3 \times 10^{4}$ \\
\hline $2.3 \times 10^{6}$ & $4.2 \times 10^{7}$ & $2,2 \times 10^{7}$ & $1.3 \times 10^{6}$ & $1.9 \times 10^{6}$ & $1.0 \times 10^{7}$ & $3.8 \times 10^{4}$ & $2.2 \times 10^{7}$ & $2.7 \times 10^{4}$ & $4.3 \times 10^{5}$ & $3.6 \times 10^{4}$ \\
\hline $7.0 \times 10^{6}$ & $9.6 \times 10^{7}$ & $4.3 \times 10^{7}$ & $4.0 \times 10^{6}$ & $1.0 \times 10^{6}$ & $1.3 \times 10^{7}$ & $9.5 \times 10^{4}$ & $1.3 \times 10^{7}$ & $3.9 \times 10^{4}$ & $2.6 \times 10^{5}$ & $6.1 \times 10^{4}$ \\
\hline $2.2 \times 10^{7}$ & $1.1 \times 10^{8}$ & $6.0 \times 10^{7}$ & $6.5 \times 10^{6}$ & $2.4 \times 10^{6}$ & $5.0 \times 10^{7}$ & $1.1 \times 10^{5}$ & $1.1 \times 10^{8}$ & $3.0 \times 10^{4}$ & $3.2 \times 10^{5}$ & $6.8 \times 10^{4}$ \\
\hline
\end{tabular}

T0 (fresh meat); T1 (thawed meat); T2 (with one part of salt); T3 (with two parts of salt); T4 (with three parts of salt); T5 (with one part of salt $+60 \mathrm{~mL}$ of "macela" extract); T6 (with one part of salt $+60 \mathrm{~mL}$ of "hibiscus" extract; T7 (with one part of salt $+60 \mathrm{~mL}$ of "laurel" extract); T8 (with one part of salt $+60 \mathrm{~mL}$ of "cinnamon" extract); T9 (with one part of salt $+60 \mathrm{~mL}$ of "clove" extract); T10 (with one part of salt $+60 \mathrm{~mL}$ of "nutmeg" extract). Values corresponding to the average of duplicates.

Descriptive comparison between Treatments with crude plant extracts and T1: by comparing the Treatments with extract T5, T6, T7, T8, T9 and T10 with $\mathrm{T} 1$, it was observed that $\mathrm{T} 5$ and $\mathrm{T} 7 \mathrm{had}$ counts of aerobic mesophilic bacteria similar to that of the Treatment with thawed meat. In other words, they had no activity that classifies them as a preservative aimed at increasing the shelf life of the meat model. However, the other Treatments had lower aerobic mesophilic bacteria count than T1. So much so that T6, T8, T9 and T10 remained suitable for consumption throughout the 15 days of the experiment, while $\mathrm{T} 5, \mathrm{~T} 7$ as well as $\mathrm{T} 1$ remained with adequate quality only until approximately the sixth day.

As will also be shown later in the text, the statistical evaluation informs that T5 and T7 do not differ from the $\mathrm{T} 2$ control, but differs from $\mathrm{T} 6, \mathrm{~T} 8$, $\mathrm{T} 9$ and $\mathrm{T} 10$.

Descriptive comparison between Treatments with extracts: Treatments T6, T8, T9 and T10 were the ones that had the lowest aerobic mesophilic count and even maintained the meat model suitable for consumption based on the microbiological parameter, over the 15 days of the experiment.

The lower multiplication of mesophilic microorganisms in these Treatments is considered to have been due to the presence of bioactive metabolite compounds, whether antimicrobial and/or antioxidants (HYGREEVA; PANDEY; RADHAKRISHNA, 2014; SILVA; DOMINGUES, 2017). An example of reference of scientific investigation on phytochemical contents found in plants is the study conducted by Valduga et al. (2019) with "hibiscus"; for "clove" references on chemical composition were found only for essential oil (KHOSRAVI et al., 2018). For ethanolic extracts there were only reports of biological activity: in "cinnamon", by Rao and Gan (2014), and in "nutmeg", by Kapoor et al. (2013).

\section{Comparison of results with those of other investigations}

The results found by Voss-Rech (2011) with "clove" extract, Husain et al. (2018) with "cinnamon" extract, Maciel et al. (2012) as well as Paim et al. (2017) with "hibiscus" extract and Panggabean, Rusmarilin and Suryanto (2019) with "nutmeg" extract confirm the same preservative potential observed in the present study.

Luzzi (2014) reports that tests with ethanolic extract of "laurel" leaves against the bacteria E. coli and Salmonella enteritidis did not show 
antimicrobial activity, which also coincides with the absence of this activity observed in this study.

Unlike this investigation, different results were observed for the Treatment with "macela" by Piovesan (2012), who evaluated the antioxidant and antimicrobial capacity of natural plant extracts in chicken sausage and found count of mesophilic and psychrotrophic aerobic microorganisms at $10^{6} \mathrm{CFU} / \mathrm{g}$ until 21 days of storage. However, there is a bias in this comparison, since the proportion of plant in the extract used in the above-mentioned study was tens of times higher than that used in this experiment. Also different was the result obtained by Silveira et al. (2014), who observed reduction in contamination by total coliforms, besides an increment of two days in product life, but using essential oil, not hydroalcoholic extract, of "laurel" in fresh Tuscan sausage.

Statistics for comparing the population density of aerobic mesophilic bacteria between $\mathrm{T} 2$ control and $\mathrm{T} 3$ to $\mathrm{T} 10$

Due to the non-normality of the $\log$ mesophilic count data, the Kruskal-Wallis nonparametric test was used to compare medians, adjusting for ties: in the comparison between all
Treatments and in the comparison between all days between them, it can be observed that there was a significant difference between Treatments and between days regarding the median value of aerobic mesophiles $(\mathrm{p}=0.000)$.

For the comparison between Treatments over the days, a comparison was made between linear trend models (using the ordinary least squares method), comparing the angular and linear coefficients of each fitted equation. The comparison showed the difference of linear coefficients between T2 (one part of salt) and T6, T8, T9 and T10, but it is not possible to affirm that this difference was significant between $\mathrm{T} 2$ and $\mathrm{T} 3, \mathrm{~T} 4, \mathrm{~T} 5$ and $\mathrm{T} 7 . \mathrm{A}$ similar result occurred in the comparison between the angular coefficients, which showed a significant difference between $\mathrm{T} 2$ and $\mathrm{T} 6, \mathrm{~T} 8, \mathrm{~T} 9$ and $\mathrm{T} 10$, but it is not possible to affirm that the difference was significant between $\mathrm{T} 2$ and $\mathrm{T} 3, \mathrm{~T} 4, \mathrm{~T} 5$ and $\mathrm{T} 7$.

\section{Description and interpretation of $\mathrm{pH}$ results compared to those of other investigations}

Table 3 shows the $\mathrm{pH}$ measurements in the meat models of the different Treatments, over 15 days of experiment.

Table 3. Daily values of $\mathrm{pH}$ in meat model (ground pork shoulder) in different Treatments, over 15 days.

\begin{tabular}{|c|c|c|c|c|c|c|c|c|c|c|c|}
\hline Day & T0 & T1 & T2 & T3 & T4 & T5 & T6 & $\mathrm{T7}$ & T8 & T9 & T10 \\
\hline 0 & 6.35 & 6.42 & 6.34 & 6.28 & 6.32 & 6.18 & 5.98 & 6.31 & 6.30 & 6.29 & 6.29 \\
\hline 1 & 6.50 & 6.25 & 6.08 & 5.96 & 5.99 & 6.32 & 6.00 & 6.29 & 6.24 & 6.28 & 6.25 \\
\hline 2 & 6.25 & 6.18 & 6.02 & 6.12 & 6.06 & 6.30 & 6.00 & 6.30 & 6.30 & 6.20 & 6.30 \\
\hline 3 & 6.37 & 6.28 & 6.09 & 5.98 & 6.03 & 6.30 & 5.90 & 6.30 & 6.30 & 6.30 & 6.40 \\
\hline 4 & 6.30 & 6.12 & 5.94 & 6.01 & 5.93 & 6.45 & 6.07 & 6.36 & 6.41 & 6.43 & 6.44 \\
\hline 5 & 6.45 & 6.03 & 5.99 & 5.97 & 5.89 & 6.40 & 6.00 & 6.20 & 6.40 & 6.40 & 6.40 \\
\hline 6 & 6.29 & 6.12 & 6.04 & 5.81 & 5.90 & 6.30 & 5.90 & 6.10 & 6.30 & 6.10 & 6.20 \\
\hline 7 & 6.23 & 6.28 & 6.06 & 6.13 & 6.07 & 6.40 & 6.00 & 6.30 & 6.30 & 6.30 & 6.37 \\
\hline 8 & 6.18 & 6.35 & 6.17 & 6.13 & 6.07 & 6.34 & 5.95 & 6.31 & 6.36 & 6.27 & 6.32 \\
\hline 9 & 6.29 & 6.10 & 5.77 & 5.76 & 5.67 & 6.52 & 6.14 & 6.65 & 6.43 & 6.27 & 6.35 \\
\hline 10 & 6.12 & 6.45 & 6.07 & 5.89 & 5.82 & 6.80 & 6.10 & 6.30 & 6.40 & 6.30 & 6.39 \\
\hline 11 & 6.54 & 6.47 & 6.07 & 5.97 & 5.85 & 6.57 & 5.84 & 6.50 & 6.44 & 6.22 & 6.41 \\
\hline 12 & 6.73 & 6.13 & 6.03 & 5.93 & 5.87 & 6.53 & 5.84 & 6.78 & 6.26 & 6.22 & 6.27 \\
\hline 13 & 6.70 & 6.65 & 6.37 & 5,96 & 6.01 & 6.52 & 5.79 & 6.67 & 6.24 & 6.21 & 6.24 \\
\hline 14 & 6.13 & 6.83 & 6.19 & 6.03 & 5.91 & 7.20 & 6.00 & 6.90 & 6.30 & 6.20 & 6.29 \\
\hline 15 & 6.63 & 6.56 & 6.26 & 5.91 & 5.97 & 7.00 & 5.80 & 6.80 & 6.20 & 6.20 & 6.23 \\
\hline
\end{tabular}

T0 (fresh meat); T1 (thawed meat); T2 (with one part of salt); T3 (with two parts of salt); T4 (with three parts of salt); T5 (with one part of salt $+60 \mathrm{~mL}$ of "macela" extract); T6 (with one part of salt $+60 \mathrm{~mL}$ of "hibiscus" extract; T7 (with one part of salt $+60 \mathrm{~mL}$ of "laurel" extract); T8 (with one part of salt $+60 \mathrm{~mL}$ of "cinnamon" extract); T9 (with one part of salt $+60 \mathrm{~mL}$ of "clove" extract); T10 (with one part of salt $+60 \mathrm{~mL}$ of "nutmeg" extract). Values corresponding to the average of duplicates. 
Statistics for significance analysis in the comparison of $\mathrm{pH}$ between $\mathrm{T} 2$ control (one part of salt) and $T 3$ to $T 10$

Kruskal-Wallis nonparametric test was used for the comparison of medians, due to the nonnormality of the $\mathrm{pH}$ data. It can be verified that there was a significant difference between Treatments regarding the median value of $\mathrm{pH}(\mathrm{p}=0.000)$. However, in a comparison of the $\mathrm{pH}$ values between days it is not possible to affirm that there is a significant difference in the median value of $\mathrm{pH}$ $(\mathrm{p}=0.9342)$.

A comparison of the angular and linear coefficients of each equation fitted to verify where the difference between the Treatments was showed difference between the control Treatment (T2) and T8, T9 and T10. However, it cannot be affirmed that the difference between linear coefficients was significant between $\mathrm{T} 2$ and T3, T4, T5, T6 and T7.

Descriptive comparison of the relationship between the results of $\mathrm{pH}$ and aerobic mesophilic bacterial count in the meat model

T3 and T4 (Treatments with higher salt contents) showed relatively similar $\mathrm{pH}$ values and also promoted similar conservation of the meat model from the point of view of aerobic bacteria count.

However, it was observed that $\mathrm{pH}$ differences for more or less in the Treatments did not seem to have been determinant in resulting in greater or lesser microbial multiplication, as is the case of T2, where there was a reduction in the $\mathrm{pH}$ value compared to $\mathrm{T} 1$, but it did not result in lower count of aerobic mesophilic bacteria.

Among the Treatments with the addition of extracts and one part of salt, it was verified that there was no recurrence in the relationship between $\mathrm{pH}$ and mesophilic count, for example the Treatment with lower $\mathrm{pH}$ also having lower count of aerobic mesophilic bacteria. Take the cases of Treatments T8, T9 and T10, which had higher $\mathrm{pH}$ compared to T6, but all promoted the same shelf life, until the fifteenth day.

Comparison of the results with those of other investigations

According to Pardi et al. (2001), pH plays a determinant role in meat quality because it influences many of its characteristics, including microbiological stability. Unlike the statement of these authors, the results obtained here, at the proportions of salt and extracts used, demonstrated that the $\mathrm{pH}$ did not influence the conservation of ground pork.

Other authors have reported results that support this study. For example, Skrökki (1997) evaluated the quality of 37 samples of ground meat and reported that, in quality control, the $\mathrm{pH}$ value is not a parameter that should be considered alone to verify whether or not the meat is suitable for consumption. The values of aerobic mesophilic microorganisms were on the order of $10^{7}$ and $10^{8}$ $\mathrm{CFU} / \mathrm{g}$, while the $\mathrm{pH}$ values were between 5.5 and 6.2. Thus, it was observed that, although the $\mathrm{pH}$ variation of most samples is within the acceptable range, several samples had high bacterial populations, which is consistent with the results obtained in this study.

Also, Forsythe (2013) states that meat is relatively buffered due to its high protein content, and the multiplication of microorganisms does not significantly reduce $\mathrm{pH}$, which corroborates the results observed in the present study.

\section{CONCLUSIONS}

Although the Treatment with highest proportion of salt (3 parts) has increased the shelf life of ground pork in comparison to Treatments with one and two parts, the statistical comparison of the median value of mesophiles did not find significant difference between them.

As for the crude extracts, those of "hibiscus", "cinnamon", "clove" and "nutmeg" kept the meat model suitable for consumption until the fifteenth day, that is, with the population of aerobic mesophilic bacteria equal to or lower than $10^{5} \mathrm{CFU} /$ g. These results confirm their potential as preservatives in meat products.

Regarding $\mathrm{pH}$, there was no relationship between it and either a higher or lower count of aerobic mesophilic microorganisms between the Treatments with the meat model.

\section{REFERENCES}

BANON, S. et al. Ascorbate, green tea and grape seed extracts increase the shelf-life of low sulphite beef patties. Meat Science, 77: 626-633, 2007.

BISSACOTTI, A. P.; ANGST, C. A.; SACCOL, A. L. F. Implicações dos aditivos químicos. Disciplinarum Scientia, 16: 43-59, 2015.

BANNWART, G. C. M. C.; SILVA, M. E. M. P.; VIDAL, G. Redução de sódio em alimentos: panorama atual e impactos tecnológicos, sensoriais e de saúde pública. Nutrire, 39: 348-365, 2014.

BRASIL, Ministério da Agricultura, Pecuária e Abastecimento. Instrução Normativa $\mathrm{n}^{\circ} \mathrm{N}^{\circ} 4$, de 31 de março de 2000. Regulamentos Técnicos de Identidade e Qualidade de Carne Mecanicamente Separada, de Mortadela, de Lingüiça e de 
Salsicha. Diário Oficial [da] República Federativa do Brasil, Brasília, DF, 05 abril 2000.

BRASIL, Ministério da Agricultura, Pecuária e Abastecimento. Instrução Normativa $n^{\circ} 62$ de 26 de Agosto de 2003. Oficializa os Métodos Analíticos Oficiais para Análises Microbiológicas para Controle de Produtos de Origem Animal e Água. Diário Oficial [da] República Federativa do Brasil, Brasília, DF,18 set. 2003.

BRASIL. Ministério da Agricultura, Pecuária e Abastecimento. Secretaria de Defesa Agropecuária. Instrução Normativa n ${ }^{\circ} 20$ de 21 de julho de 1999. Oficializa os Métodos Analíticos Físico-Químicos, para Controle de Produtos Cárneos e seus Ingredientes - Sal e Salmoura. Diário Oficial [da] República Federativa do Brasil, Brasília, DF, 21 julho 1999, republicada Diário Oficial [da] República Federativa do Brasil, Brasília, DF,9 set 1999.

BRASIL. Agência Nacional de Vigilância Sanitária. Resolução (RDC) $\mathbf{n}^{\circ} \mathbf{1 2}$, de 02 de janeiro de 2001. Aprova o Regulamento Técnico sobre Padrões Microbiológico para Alimentos. Disponível em: $<$ http://portal.anvisa.gov.br/ documents/33880/2568070/ RDC 12 2001.pdf/15ffddf6-3767-4527-bfac$740 \mathrm{a} 0400829 \mathrm{~b}>$. Acesso em: 06 maio 2017.

FORSYTHE, S. J. Microbiologia da segurança dos alimentos. 2. ed. Porto Alegre, RS: 37 Artmed, 2013. 607 p.

GYAWALI, R.; IBRAHIM, S. A. Natural products as antimicrobial agents. Food Control, 46: 412-429, 2014.

HAFSA, J. et al. Physical, antioxidant and antimicrobial properties of chitosan films containing Eucalyptus globulus essential oil. Food Science and Technology, 68: 356-364, 2016.

HUSAIN, I. et al. Phytochemical characterization and biological activity evaluation of ethanolic extract of Cinnamomum zeylanicum. Journal of Ethnopharmacology, 219: 110-116, 2018.

HYGREEVA, D.; PANDEY, M. C.; RADHAKRISHNA, K. Potential applications of plant based derivatives as fat replacers, antioxidants and antimicrobials in fresh and processed meat products. Meat Science, 98: 47-57, 2014.

INETIANBOR, J.; YAKUBU, J.; EZEONU, S. Effects of food additives and preservatives on man-a review. Asian Journal of Science and Technology, 6: 1118-1135, 2016.
JAVANMARDI, F. et al. The association between the preservative agents in foods and the risk of breast cancer. Nutrition and Cancer, 71: 1229-1240, 2019.

JAY, J. M. Microbiologia de Alimentos. 6 ed. Porto Alegre, RS: Artmed, 2005. $711 \mathrm{p}$

KAPOOR, I. P. S. et al. Chemical Composition and Antioxidant Activity of Essential Oil and Oleoresins of Nutmeg (Myristica fragrans Houtt.) Fruits. International Journal of Food Properties, 16: 1059-1070, 2013.

KHOSRAVI, A. R. et al. Chemical composition, antioxidant activity and antifungal effects of five Iranian essential oils against Candida strains isolated from urine samples. Journal de Mycologie Médicale, 28: 355-360, 2018.

KIM, S. J.; CHO, A. R.; HAN, J. Antioxidant and antimicrobial activities of leafy green vegetable extracts and their application to meat product preservation. Food Control, 29: 112-120, 2013.

LUZZI, J. C. Atividade antimicrobiana do extrato etanólico de folhas de louro - Laurus nobilis frente às bactérias Escherichia coli e Salmonella enteritidis. 2010. 71 f. Monografia (Curso Química Industrial). Universidade do Vale do Taquarí (UNIVATES), Lajeado/RS, 2014.

MACIEL, M. J. et al. Avaliação do extrato alcoólico de hibisco (Hibiscus sabdariffa L.) como fator de proteção antibacteriana e antioxidante. Revista do Instituto Adolfo Lutz (Impr.), 71: 462-470, 2012.

NILSON, E. A. F.; JAIME, P. C.; RESENDE, D. O. Iniciativas desenvolvidas no Brasil para a redução do teor de sódio em alimentos processados. Revista Parnamericana de Salud Publica, 34: 287- 92, 2012.

PANGGABEAN, K. A.; RUSMARILIN, H.; SURYANTO, D. The utilization of nutmeg seed (Myristica fragrans Houtt) extract as an antimicrobial on tempeh sausage. IOP Conference Series: Earth and Environmental Science, 260, 2019. Article number 012087. Disponível em: < https://iopscience.iop.org/article/10.1088/1755-94 1315/260/1/012087/pdf>. Acesso em: 15 jul 2019.

PAIM, M. P. et al. Anti-Escherichia coli effect of Hibiscus sabdariffa L. in a meat model. Food Science and Technology, 37: 647-650, 2017.

PARDI, M. C. et al. Ciência, higiene e tecnologia da carne: tecnologia da sua obtenção e transformação. Goiania, GO : Editora da UFG, $2001.623 \mathrm{p}$. 
PISOSCHI, A. M. et al. An overview of natural antimicrobials role in food. European Journal of Medicinal Chemistry, 143: 922-935, 2018.

PIOVESAN, N. Extratos naturais de sementes de mamão papaya (Carica papaya L.) e marcela (Achyrocline satureioides) e avaliação da capacidade antioxidante e antimicrobiana em linguiça de frango. 2012. 65 f. Dissertação (Mestrado em Ciência e Tecnologia de Alimentos) Universidade Federal de Santa Maria, Santa Maria, 2012.

RAO, P. V.; GAN, S. H. Cinnamon: A Multifaceted Medicinal Plant. Evidence-Based Complementary and Alternative Medicine, 2014: 642942, 2014.

SANTOS, C. B. et al. Preparo e caracterização de tinturas das folhas de chá verde [Camellia sinensis (L.) O. Kuntze] Theaceae. Revista Brasileira de Plantas Medicinais, 16: 826-831, 2014.

SCAPIN, T.; FERNANDES, A. C.; PROENÇA, R. P. C. Açúcares de adição: definições,classificações, metabolismo e implicações à saúde. Revista de Nutrição, 30: 663-677, 2017.

SHARIF, Z. I. M. et al. Review on methods for preservation and natural preservatives for extending the food longevity. Engineering Research Bulletin, 19: 145-153, 2017.

SILVA, F.; DOMINGUES, F. C. Antimicrobial activity of coriander oil and its effectiveness as food preservative. Critical Reviews in Food Science and Nutrition, 57: 35-47, 2017.

SILVEIRA, S. M. et al. Chemical composition and antibacterial activity of Laurus nobilis essential oil towards foodborne pathogens and its application in fresh Tuscan sausage stored at $7^{\circ} \mathrm{C}$. Food Science and Technology, 59: 86-93, 2014

SIMÕES, C. M. O. et al. Farmacognosia: da planta ao medicamento. 5. ed. Porto Alegre, RS/ Florianópolis, SC: Editoras da UFRGS/UFSC, 2003. $315 \mathrm{p}$.

SINGH, A.; SHARMA, P. K.; GARG, G. Natural products as preservatives. International Journal of Pharma and Bio Science, 1: 601-612, 2010.

SKRÖKKI, A. Hygienic quality of commercial minced meat as indicated by aerobic microorganisms and Coliform bacteria. Zeitschrift Für Lebensmittel-Untersuchung Und Florschung A, 204: 391-394, 1997.
SULTANA, T. et al. Microbiological analysis of common preservatives used in food items and demonstration of their in vitro anti-bacterial activity. Asian Pacific Journal of Tropical Disease, 4: 452456, 2014.

VALDUGA, A. T. et al. Chemistry, pharmacology and new trends in traditional functional and medicinal beverages. Food Research International, 120: 478-503, 2019

VASCONSELOS, M. A. S.; MELO FILHO, A. B. Conservação de alimentos. Recife, PE: EDURPE, 2010. $130 \mathrm{p}$

VOSS-RECH, D. et al. Antibacterial activity of vegetal extracts against serovars of Salmonella. Ciência Rural, 41: 314-320, 2011.

ZAKNUN, D. et al. Potential role of antioxidant food supplements, preservatives and colorants in the pathogenesis of allergy and asthma. International Archives of Allergy and Immunology, 157: 113124,2012 